\title{
Analysis on Public Risk Perception and Environmental Risk
}

\author{
Hwang, Seong-Nam*
}

\begin{abstract}
This research examined how Scientifically Estimated Environmental Risks (SEERs) of floods, hurricanes, and hazardous material releases are related with perceived risks of those hazards. This study also tested the relationship between household characteristics and environmental risk perceptions. Major findings of this research are as follows. First, there were little differences in risk perceptions of natural and technological hazards across demographic groups. Specifically, the respondents' risk perceptions of both natural and technological hazards did not differ by age, household size, and marital status. By contrast, educational level, gender ( $m a l e=1$ ), and median household income were statistically related to perceived risk of the natural hazards, whereas educational attainment and gender were statistically related to perceived risk of hazardous material releases. Finally, SEERs of floods and hurricanes were positively related to respondents' perception of property damage, but not related to injury or heath problems from those natural hazards. SEER of hazardous materials was related to all three categories of risk perception of a hazardous material release. These results suggest that environmental cues such as proximity to rivers and bays do not much contribute to an increase in the respondents' perception of safety and health problems resulting from natural hazards. The fact that there was a significant correlation with property damage suggests that risk area residents believe that they can protect themselves (e.g., by evacuating), but not their property.
\end{abstract}

Key words : emergency management, natural disaster, environmental hazard, urban planning, disaster planning

\section{요 지}

이 연구는 과학적으로 측정된 자연재해(홍수, 허리케인영향지역) 및 인적재난(위험물질 근접지역) 위험지수가 거주민들의 그 재해에 대한 인지도에 어떻게 영향을 끼치는지를 조사하였다. 이 연구는 더불어 연구 대상지역의 인구적 특성과 각각의 재해에 대한 위험 인지도가 어떤 상관관계를 갖는지를 테스트하였다. 주요 연구결과는 다음과 같다. 첫째, 인구적 특성들(연령, 성별, 가족구성의 크기, 결혼여부, 주택거주기간)과 자연재해(홍수/허리케인)와 인적재난(위험물질 측정치)에 대한 위험 인지도 사이에 는 통계적인 상관관계가 없었다. 대조적으로 교육수준, 성별, 가족의 수입은 자연재해에 대한 인지도와 통계적으로 의미 있는 상관관계가 있었다. 한편, 교육수준과 성별은 인적재난에 대한 인지도와 통계적으로 의미 있는 상관관계가 있었다. 자연재해(홍 수와 허리케인)에 대해 과학적으로 측정된 위험지수는 재해로 인한 재산상의 손실예측에 대한 인지도와 통계적인 상관관계가 있었다. 그러나 그 위험지수는 자연재해로 인한 상해나 건강상의 위험에 대한 인지도와는 상관관계가 없었다. 전체적으로 말해 서, 이 연구 결과는 강이나 바다의 근처에 주거지를 갖진 사람들이 자연재해로부터 자신 및 가족의 안전 및 건강위해 가능성 에 대한 위험 인식도가 낮음을 보여주고 있다. 하지만 이러한 위험지역에 위치한 거주민들이 재해로 인한 자신의 주거지가 손 상을 입을 가능성에 대한 인식은 통계적으로 의미 있게 나타나고 있다. 이는 그들이 자신 및 가족은 재해 위험으로부터 대피 함으로써 생명을 보호할 수 있지만 자신의 주택은 그렇게 할 수 없기 때문인 것으로 추정된다.

핵심용어 : 방재, 환경재해, 인적재난, 홍수위험, 도시계획, 방재계획

\section{Introduction}

Previous studies showed that individualsí perception of environmental risk rests upon a variety of personal, cultural, social, demographic, and economic factors. A critical limitation of prior research is that existing research has failed to investigate the difference between scientifically estimated risks and perceived risks to see if these are significantly related. This may be problematic if, as is likely, the esti- mated risk is not related to perceived risk.

Therefore, this study will test whether scientifically estimated environmental risks are related to public risk perceptions of the three multiple hazards (floods, hurricanes, and hazardous material releases). The study objectives are to test whether scientifically estimated risk and perceived risk of multiple hazards are related to residentsí household characteristics, and to test whether scientifically estimated risk of multiple hazards is related to residentsí perceived risk of those hazards. 


\section{Literature Review}

Risk is defined as measuring the probability of the occurrence of natural and technological hazards leading to certain adverse consequences (Kates and Kasperson, 1983; Cutter, 1993). Like the definition of environmental risk, environmental risk perception has been defined in slightly different ways by several disaster experts. According to Mileti, Drabek and Haas (1975), risk perception is referred to as the individualís understanding of the character and relevance of a hazard. Sorensen and White (1980) similarly define risk perception as an individualís understanding of the temporal nature, probability, and the potential consequences of the disaster caused by a hazard. In the context of this study, environmental risk perception is defined as oneís beliefs about individual hazards that are caused or induced by nature and humans. Slovic (1987) defines risk perception as the intuitive judgments people make in evaluating environmental risks. The psychometric paradigm of public risk perception studies uses an experimental approach and quantitative methods to create cognitive maps of public risk perception (Liu, 1996). The psychometric model maintains that public risk perception is a function of various risk attributes, such as voluntary and involuntary risk (Starr, 1969), new and old risk (Sjoberg, 2002), dread risk and common risk, and known and unknown risk (Slovic, 1987). As such, peopleís perceived risks are closely linked to the location of a hazard within the two dimensional space (Liu, 1996). Recent research has examined how risk perception varies across social, economic, and demographic groups (Slovic, 1992; Liu, 1996).

Individualsí perceived risk plays a major role in determining how they respond to environmental hazards by interpreting warning messages or taking protective actions against hazard events (Lindell \& Perry, 1992; Burn, 1999). Slovic (1987) argues that individuals build upon risk perception to estimate dangerous situations during emergencies.

\section{Hypotheses}

\subsection{Rationale 1}

Some research shows that environmental risk perception is positively correlated with higher socioeconomic status (Taylor, 1989; Van Liere \& Dunlap, 1980). In particular, previous studies maintained that higher public risk perception was found among females (Slovic, 1992; Savage, 1993), ethnic minorities (Adeola, 1995), less educated, poorer people (Pilisuk \& Acredolo, 1988), younger people, and lowincome groups (Savage, 1993).

Hypothesis 1: Public risk perceptions of floods, hurricanes, and toxic chemical releases are related to household characteristics.

\subsection{Rationale 2}

Slovic (1987) defines public risk perception as the intuitive judgments people make in evaluating environmental risks. Scientific assessments of the risks of natural and technological hazards are based upon scientifically estimated data, but these are generally based upon proximity to the hazard source. Thus, risk area residentsí perceptions could be related to SEERs either because authorities have informed them of the risk directly, because peers (friends, relatives, neighbors and coworkers) have transmitted this information, because they have obtained SEERs through the mass media, or because they are basing their risk perception on the same environmental cues (proximity to rivers, bays, and chemical plants), as scientists use in computing SEERs (Drabek, 1986).

Hypothesis 2: Scientifically estimated environmental risks of natural and technological hazards are positively related to public risk perceptions of floods, hurricanes, and toxic chemical releases.

\section{Methods and Data}

The study consists of: 1) mail survey data on respondentsí perceptions of environmental risks and their socio/economic/demographic characteristics; and 2) spatial data on three types of environmental risks (i.e., flood, hurricane, and chemical risk). Correlational analyses were implemented to empirically test relationships of household characteristics with scientifically estimated environmental risk (SEER) and perceived risk, as well as the relationship between SEER and individualsí perceived risk.

The target population for this research consisted of singlefamily dwelling owners residing within Harris County in Texas in 2002. The unit of analysis used to test the hypothesis was the single-family housing unit and the household that owned it. The methods used to investigate the six hypotheses that were specified in the previous chapter included a mail survey, geographic information systems (GIS) modeling, and statistical analyses.

To randomly sample the required number of respondents, a list of countywide single-family residential property records (the sample frame of this study) was obtained from the Harris County Appraisal District. Based upon the residential parcel records, stratified random sampling was employed to select 800 households. There were four stratification variables that were defined by the three environmental hazards (floods, hurricanes and chemical releases) and a no-risk area. Two hundred households were selected that were vulnerable to each hazard. In the cases selected for flood risk, the FEMAís flood insurance map for Harris County in Texas was used to randomly select 100 households in the 100-year flood plain and 100 households in the 
Table 1. Household characteristics of the respondents

\begin{tabular}{|c|c|c|c|c|c|c|c|}
\hline \multicolumn{2}{|r|}{ Variables } & \multirow{2}{*}{$\frac{\mathrm{F}^{*}}{52}$} & \multirow{2}{*}{$\begin{array}{c}\% \\
16.2 \\
\end{array}$} & \multicolumn{2}{|c|}{ Variables } & \multirow{2}{*}{$\frac{F^{*}}{31}$} & \multirow{2}{*}{$\begin{array}{c}\% \\
9.7\end{array}$} \\
\hline \multirow{5}{*}{ Age } & $20 \mathrm{~s}$ to $30 \mathrm{~s}$ & & & Tenure & $15-19$ yrs & & \\
\hline & $40 \mathrm{~s}$ & 92 & 28.7 & \multirow{10}{*}{ Income } & Over 20 yrs & 77 & 24 \\
\hline & $50 \mathrm{~s}$ & 82 & 25.5 & & Missing & 4 & 1.2 \\
\hline & $60 \mathrm{~s}$ & 79 & 24.6 & & Less than $\$ 14,000$ & 6 & 1.9 \\
\hline & Missing & 16 & 5 & & $\$ 14,000-\$ 23,999$ & 19 & 5.9 \\
\hline \multirow{6}{*}{ Education } & Less than high school & 10 & 3.1 & & $\$ 24,000-\$ 34,999$ & 28 & 8.7 \\
\hline & High school/ GED & 43 & 13.4 & & $\$ 35,000-\$ 49,999$ & 24 & 7.5 \\
\hline & Some college & 90 & 28 & & $\$ 50,000-\$ 70,000$ & 57 & 17.8 \\
\hline & College graduate & 94 & 29.3 & & $\$ 70,000-\$ 100,000$ & 73 & 22.7 \\
\hline & Graduate degree & 78 & 24.3 & & Over $\$ 100,000$ & 72 & 22.4 \\
\hline & Missing & 6 & 1.9 & & Missing & 42 & 13.1 \\
\hline \multirow{3}{*}{ Gender } & Male & 193 & 60.1 & \multirow{5}{*}{$\begin{array}{c}\text { Marital } \\
\text { status }\end{array}$} & Married & 235 & 73.2 \\
\hline & Female & 114 & 35.5 & & Single & 21 & 6.5 \\
\hline & Missing & 14 & 4.4 & & Divorced & 43 & 13.4 \\
\hline \multirow{5}{*}{$\begin{array}{l}\text { Household } \\
\text { size }\end{array}$} & 1 & 49 & 15.3 & & Widowed & 18 & 5.6 \\
\hline & 2 & 116 & 36.1 & & Missing & 4 & 1.2 \\
\hline & 3 & 66 & 20.6 & \multirow{6}{*}{$\begin{array}{l}\text { Ethnic } \\
\text { identity }\end{array}$} & Black & 28 & 8.7 \\
\hline & 4 & 49 & 15.3 & & White & 212 & 66 \\
\hline & Over 5 & 41 & 12.7 & & Hispanic & 34 & 10.6 \\
\hline \multirow{3}{*}{ Tenure } & $1-4$ yrs & 103 & 32.1 & & Asian & 16 & 5 \\
\hline & $5-9$ yrs & 64 & 19.9 & & Others & 13 & 4.1 \\
\hline & $10-14 y r s$ & 42 & 13.1 & & Missing & 18 & 5.6 \\
\hline
\end{tabular}

$\mathrm{F}^{*}$ : Frequency

500-year flood plain. In the cases selected for hurricane risk, 40 cases were selected from households located in each of the five hurricane risk areas. In the cases selected for chemical risk, 40 cases were randomly selected at increments of 0.5 mile from zero to 2.5 miles from the nearest hazardous material facility. The remaining 200 households were randomly selected from an area comparatively free from these three types of hazards. Statistical power analysis showed that a sample size of 800 would have a $95 \%$ confidence interval with 0.035 sampling error. A total of 321 out of the sampled 800 single-family homeowners returned questionnaires until December 31, 2003 for a gross response rate of $40.1 \%$. However, one household was no longer at its original address, and two households turned out to live outside the study area. Because these three households were not replaced, this yielded an adjusted response rate of $40.4 \%$.

The household characteristics (namely, social, economic, and demographic characteristics) of the respondents (single family residential owners) are shown in Table 1.

\subsection{Variables and Measurement}

The mail survey included self-reports of single-family residential ownersíperceived risks, and social, economic and demographic features. As shown in Table 2, they were requested to rate their level of concern about the likelihood of "Major damage to your home", "Injury to you or members of your household", and "Health problems to you or members of your household" for floods, hurricane, hazardous material releases within the next 10 years. The response scales for risk perception were rated by "Not at all likely" $(=1)$ and "Almost a certainty" $(=5)$.

By using GIS techniques, the spatial distribution of risk from flood, hurricane, and hazardous material facilities was delineated and then overlaid onto the parcel map that contained the locations of sampled housing units. Table 3 describes the variables, their concepts, and the operational measures for environmental risk of floods, hurricanes, and hazardous material releases.

Flood risk was assessed using the Federal Emergency Management Agency's (FEMA) Flood Insurance Rate Map (FIRM) for year 1996 in Harris County in Texas. This map identified areas most susceptible to flooding, which correspond to the 100- and 500-year flood plains. The 100-year flood plain (YFP) is the area that has an expected recurrence interval of 100 years, whereas the 500-YFP has an expected recurrence interval of 500 years. Flood risk areas were overlapped with the parcel map of the survey respondents' housing units to determine the level of flood risk at the housing 
Table 2. Concept, variable, and operational measure of environmental risk perception

\begin{tabular}{|c|c|c|}
\hline Concept & Variables & Operational Measures \\
\hline \multirow{9}{*}{$\begin{array}{l}\text { Perceived Natural/ } \\
\text { Technological Risk }\end{array}$} & \multirow{3}{*}{ Perceived flood risk } & Rated concern about property damage to home \\
\hline & & Rated concern about injury to family \\
\hline & & Rated concern about health problems to family \\
\hline & \multirow{3}{*}{ Perceived hurricane risk } & Rated concern about property damage to home \\
\hline & & Rated concern about injury to family \\
\hline & & Rated concern about health problems to family \\
\hline & \multirow{3}{*}{ Perceived chemical risk } & Rated concern about property damage to home \\
\hline & & Rated concern about injury to family \\
\hline & & Rated concern about health problems to family \\
\hline
\end{tabular}

Table 3. Concept, variable, and operational measure of environmental risk

\begin{tabular}{|c|c|l|}
\hline Concept & Variables & \multicolumn{1}{c|}{ Operational Measures } \\
\hline \multirow{3}{*}{$\begin{array}{c}\text { Natural/ } \\
\text { Technological Risk }\end{array}$} & $\begin{array}{c}\text { Scientifically estimated } \\
\text { flood risk }\end{array}$ & $\begin{array}{l}\text { Each floodplain zone is rated by the probability of flood occurrence. The 100-YFP } \\
\text { zone is rated with the highest value of "5", and the 500-YFP zone rated with the } \\
\text { second lowest value of "1" while the zone without the flood risk is rated with the } \\
\text { lowest value of "0" }\end{array}$ \\
\cline { 2 - 3 } & $\begin{array}{c}\text { Scientifically estimated } \\
\text { hurricane risk }\end{array}$ & $\begin{array}{l}\text { Five zones of hurricane risk areas and one zone of non-risk area are used, and } \\
\text { displayed on top of the map of the respondents' houses to assign each of the } \\
\text { housing units to the relevant value with the highest rating of "5" and the lowest } \\
\text { rating of "0", depending upon the risk zone. }\end{array}$ \\
\cline { 2 - 3 } & $\begin{array}{c}\text { Scientifically estimated } \\
\text { chemical risk }\end{array}$ & Distance between house and its nearest Toxic Release Inventory (TRI) site. \\
\hline
\end{tabular}

unit level. The 100-YFP areas were given an index of " 5 " since they were the most susceptible to flooding, while the 500 -YFP areas were indexed as "1" since they are less susceptible to flood damage. The areas outside the 500-YFP were indexed " 0 ".

To identify the hurricane risk areas, the hurricane risk area boundary map was used that was developed at the Hazard Reduction \& Recovery Center at Texas A\&M University for the Texas Division of Emergency Management. Using the Saffir/Simpson scale, this map divides hurricane risk areas into five categories that correspond to a hurricane's intensity. Specifically, hurricane risk areas were estimated using a computer program, called SLOSH (Sea, Lake, and Overland Surges from Hurricanes) to define risk areas from storm surge and the Inland Wind Decay Model to define risk areas from hurricane-driven wind (Lindell et al., 2001). The most susceptible areas are those that lie along the shoreline, at low elevations, or close to the waterfront. Thus, populations living in hurricane Risk Area 1 would be most vulnerable to surge and wind damage in the event of all category hurricanes. As one moves farther inland, populations become less vulnerable to wind and surge action from a hurricane. With the exception of areas free from hurricane hazard, the area identified as Risk Area 5 is least subject to a hurricane and would only be affected by flooding and wind damage in the event of a Category 5 hurricane. The hurricane risk area map was superimposed upon the parcel map to decide each housing unit's hurricane risk level. Hurricane Risk Area 1 was given a index of "5" since the area was the most susceptible to all categories of hurricanes, while hurricane Risk Area 5 was rated as " 1 " since the area was susceptible only to a Category 5 hurricane. Areas outside these hurricane categories were indexed as " 0 ".

The measure of chemical risk was based upon Toxic Release Inventory (TRI) facility data for 2000. This data base was developed and published on the Internet by the U.S. Environmental Protection Agency (http://www.epa.gov/ tri/). As of 2000, there were 2206 TRI sites in Harris County. The data base has information on the locations, types and quantities of nearly 650 chemicals being stored on-site, the types and amounts of toxic chemical annually being released into the environment, and other waste management activities from various industries that use, store, and produce hazardous chemicals or materials.

GIS made it possible to geocode the TRI sites by means of their latitudes and longitudes. The TRI location map was overlapped with the parcel map to measure the distance from each respondent housing unit to its nearest TRI site.

\section{Results}

\subsection{Perceived Risks}

As mentioned in Chapter V, the survey respondents used a five-category Likert scale to rate their concerns of future 
Table 4. Descriptive characteristics of risk perception

\begin{tabular}{|c|c|c|c|c|c|}
\hline Variable & Measures & Acronym* & Mean & Std. Deviation & $\mathrm{N}$ \\
\hline \multirow{3}{*}{$\begin{array}{c}\text { Risk perception of } \\
\text { a flood }\end{array}$} & Property damage & PDF & 2.57 & 1.19 & 320 \\
\cline { 2 - 6 } & Injury & IJF & 1.89 & 0.93 & 317 \\
\cline { 2 - 6 } & Health problems & HPF & 2.21 & 1.15 & 317 \\
\hline \multirow{3}{*}{$\begin{array}{c}\text { Risk perception of } \\
\text { a hurricane }\end{array}$} & Property damage & PDH & 3.02 & 1.11 & 316 \\
\cline { 2 - 6 } & Injury & IJH & 2.28 & 0.98 & 315 \\
\hline \multirow{3}{*}{$\begin{array}{c}\text { Risk perception of } \\
\text { a hazardous material release }\end{array}$} & Health problems & HPH & 2.29 & 1.06 & 315 \\
\cline { 2 - 6 } & Property damage & PDHM & 2.10 & 1.09 & 318 \\
\cline { 2 - 6 } & Injury & IJHM & 2.24 & 1.13 & 318 \\
\hline
\end{tabular}

*PDF: property damage from a flood; IJF: injury from a flood; HPF: health problems from a flood; PDH: property damage from a hurricane; IJH: injury from a hurricane; HPH: health problems from a hurricane; PDHM : property damage from a hazardous material release; IJHM: injury from a hazardous material release; HPHM: health problems from a hazardous material release

Table 5. Number and frequency of each level of risk perception on floods

\begin{tabular}{|c|c|c|c|c|c|c|}
\hline \multirow{2}{*}{ Level } & \multicolumn{2}{|l|}{ Property Damage } & \multicolumn{2}{|c|}{ Injury } & \multicolumn{2}{c|}{ Health Problems } \\
\cline { 2 - 7 } & $\mathrm{n}$ & $\%$ & $\mathrm{n}$ & $\%$ & $\mathrm{n}$ & $\%$ \\
\hline 1 & 66 & 20.6 & 129 & 40.2 & 103 & 32.1 \\
\hline 2 & 98 & 30.5 & 113 & 35.2 & 104 & 32.4 \\
\hline 3 & 91 & 28.3 & 61 & 19 & 70 & 21.8 \\
\hline 4 & 38 & 11.8 & 8 & 2.5 & 20 & 6.2 \\
\hline 5 & 27 & 8.4 & 6 & 1.9 & 20 & 6.2 \\
\hline Total & 320 & 99.7 & 317 & 98.8 & 317 & 98.8 \\
\hline Missing & 1 & 0.3 & 4 & 1.2 & 4 & 1.2 \\
\hline Total & 321 & 100 & 321 & 100 & 321 & 100 \\
\hline
\end{tabular}

Table 6. Number and frequency of each level of risk perception on hurricanes

\begin{tabular}{|c|c|c|c|c|c|c|}
\hline \multirow{2}{*}{ Level } & \multicolumn{2}{|c|}{ Property Damage } & \multicolumn{2}{|c|}{ Injury } & \multicolumn{2}{c|}{ Health Problems } \\
\cline { 2 - 7 } & $\mathrm{n}$ & $\%$ & $\mathrm{n}$ & $\%$ & $\mathrm{n}$ & $\%$ \\
\hline 1 & 25 & 7.8 & 75 & 23.4 & 87 & 27.1 \\
\hline 2 & 78 & 24.3 & 110 & 34.3 & 94 & 29.3 \\
\hline 3 & 118 & 36.8 & 105 & 32.7 & 101 & 31.5 \\
\hline 4 & 56 & 17.4 & 16 & 5.0 & 21 & 6.5 \\
\hline 5 & 39 & 12.1 & 9 & 2.8 & 12 & 3.7 \\
\hline Total & 316 & 98.4 & 315 & 98.1 & 315 & 98.1 \\
\hline Missing & 5 & 1.6 & 6 & 1.9 & 6 & 1.9 \\
\hline Total & 321 & 100.0 & 321 & 100.0 & 321 & 100.0 \\
\hline
\end{tabular}

major consequences from hurricanes, floods, and hazardous material releases. Table 4 shows the means, standard deviations, the number of cases, minimums, and maximums for the respondents' risk perceptions. Tables 5 through 7 show the number of cases and the percentages for the risk perception items measured. Perceptions of consequences resulting from a flood and hurricane increased gradually from injury, through health problems, to property damage. Conversely, their perceived risk of a hazardous material release
Table 7. Number and frequency of each level of risk perception on hazardous material releases

\begin{tabular}{|c|c|c|c|c|c|c|}
\hline \multirow{2}{*}{ Level } & \multicolumn{2}{|c|}{ Property Damage } & \multicolumn{2}{|c|}{ Injury } & \multicolumn{2}{c|}{ Health Problems } \\
\cline { 2 - 7 } & $\mathrm{n}$ & $\%$ & $\mathrm{n}$ & $\%$ & $\mathrm{n}$ & $\%$ \\
\hline 1 & 119 & 37.1 & 103 & 32.1 & 89 & 27.7 \\
\hline 2 & 92 & 28.7 & 90 & 28.0 & 84 & 26.2 \\
\hline 3 & 73 & 22.7 & 84 & 26.2 & 89 & 27.7 \\
\hline 4 & 23 & 7.2 & 27 & 8.4 & 35 & 10.9 \\
\hline 5 & 11 & 3.4 & 14 & 4.4 & 21 & 6.5 \\
\hline Total & 318 & 99.1 & 318 & 99.1 & 318 & 99.1 \\
\hline Missing & 3 & 0.9 & 3 & 0.9 & 3 & 0.9 \\
\hline Total & 321 & 100.0 & 321 & 100.0 & 321 & 100.0 \\
\hline
\end{tabular}

increased gradually from property damage, to injury, and to health problems. Overall, the respondents' perception of property damage to the respondents' home from a hurricane yielded the highest mean $(\mathrm{M}=3.02)$, followed by property damage from a flood $(\mathrm{M}=2.57)$, and by health problems from a hazardous material release $(\mathrm{M}=2.42$; see Table 4$)$. Conversely, the mean for the perception of injury to the respondents from a flood $(\mathrm{M}=1.89)$ was lowest, followed by property damage from a hazardous material release $(\mathrm{M}=$ 2.10).

Correlational analyses were conducted to examine the overall relationship between household characteristics and risk perception items addressing the major environmental concerns from floods, hurricanes, and hazardous material releases (see Table 8). AGE, HSIZE (household size) and STATUS (marital status) showed no significant relationship with any risk perception items. EDU had a significant relationship with perceived risk of property damage from a flood (PDF), injury from a hurricane (IJH), health problems from a hurricane (HPH), and property damage from a hazardous material release (PDHM) with correlation coefficients of $-0.15,-0.15,-0.12$, and -0.11 , respectively. These 
Table 8. Correlation coefficients of household characteristics with risk perception

\begin{tabular}{|c|c|c|c|c|c|c|c|c|c|c|c|c|c|c|c|c|}
\hline & 1 & 2 & 3 & 4 & 5 & 6 & 7 & 8 & 9 & 10 & 11 & 12 & 13 & 14 & 15 & 16 \\
\hline 1. AGE & 1.00 & & & & & & & & & & & & & & & \\
\hline 2. EDU & -0.03 & 1.00 & & & & & & & & & & & & & & \\
\hline 3. SEX & 0.04 & 0.11 & 1.00 & & & & & & & & & & & & & \\
\hline 4. HSIZE & $-0.30 * *$ & -0.06 & 0.06 & 1.00 & & & & & & & & & & & & \\
\hline 5. INCOME & $-0.27 * *$ & $0.42 * *$ & $0.20^{* *}$ & 0.12 & 1.00 & & & & & & & & & & & \\
\hline 6. STATUS & -0.10 & 0.01 & $0.37^{* *}$ & $0.38 * *$ & $0.40^{* *}$ & 1.00 & & & & & & & & & & \\
\hline 7. TENURE & $0.62 * *$ & $-0.13^{*}$ & -0.10 & $-0.23 * *$ & $-0.31 * *$ & $-0.17^{* *}$ & 1.00 & & & & & & & & & \\
\hline $8 . \mathrm{PDF}$ & 0.00 & $-0.15^{* *}$ & -0.11 & -0.07 & \begin{tabular}{|l|}
-0.11 \\
\end{tabular} & $\mid-0.09$ & 0.07 & 1.00 & & & & & & & & \\
\hline 9. IJF & -0.07 & -0.11 & $-0.15^{*}$ & 0.07 & -0.09 & -0.03 & -0.03 & $0.55^{* *}$ & 1.00 & & & & & & & \\
\hline 10. HPF & 0.00 & -0.07 & $-0.13^{*}$ & 0.03 & $-0.17 * *$ & -0.09 & 0.09 & $0.64 * *$ & $0.68 * *$ & 1.00 & & & & & & \\
\hline 11. PDH & 0.07 & -0.11 & $-0.15^{* *}$ & -0.05 & $-0.14 *$ & -0.09 & $0.17 * *$ & $0.63 * *$ & $0.35^{* *}$ & $0.43 * *$ & 1.00 & & & & & \\
\hline 12. IJH & 0.00 & $-0.15^{* *}$ & $-0.17 * *$ & 0.03 & -0.08 & -0.05 & 0.07 & $0.45^{* *}$ & $0.60^{* *}$ & $0.55^{* *}$ & $0.57^{* *}$ & 1.00 & & & & \\
\hline 13. HPH & 0.05 & $-0.12^{*}$ & $-0.16^{* *}$ & -0.01 & $-0.13^{*}$ & -0.07 & 0.10 & $0.47 * *$ & $0.58^{* *}$ & $0.70 * *$ & $0.55^{* *}$ & $0.82 * *$ & 1.00 & & & \\
\hline 14. PDHM & 0.02 & $-0.11^{*}$ & $-0.22 * *$ & 0.05 & -0.10 & -0.09 & 0.06 & $0.32 * *$ & $0.43^{* *}$ & $0.45 * *$ & $0.41^{* *}$ & $0.50 * *$ & $0.55 * *$ & 1.00 & & \\
\hline 15. IJHM & -0.01 & -0.08 & $-0.16^{* *}$ & 0.07 & -0.09 & -0.06 & 0.04 & $0.31^{* *}$ & $0.41^{* *}$ & $0.46^{* *}$ & $0.39^{* *}$ & $0.47 * *$ & $0.51 * *$ & $0.85^{* *}$ & 1.00 & \\
\hline 16. НРHМ & 0.00 & -0.05 & $-0.17 * *$ & 0.05 & -0.07 & -0.03 & 0.08 & $0.28 * *$ & $0.33^{* *}$ & $0.48 * *$ & $0.34 * *$ & $0.40 * *$ & $0.48 * *$ & $0.75 * *$ & $0.88^{* *}$ & 1.00 \\
\hline
\end{tabular}

1. age on last birthday; 2: educational attainment; 3 : sex (males $=1$ ); 4: household size; 5 : yearly household income; 6 : marital status (married = 1); 7: tenure; 8: property damage from a flood; 9: injury from a flood; 10: health problems from a flood; 11: property damage from a hurricane; 12 : injury from a hurricane; 13 : health problems from a hurricane; 14: property damage from a hazardous material release; 15: injury from a hazardous material release; 16: health problems from a hazardous material release.

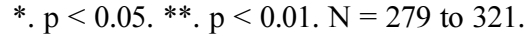

Table 9. Correlation coefficients of environmental risks with risk perception

\begin{tabular}{|c|c|c|c|c|c|c|c|c|c|c|c|c|}
\hline & 1 & 2 & 3 & 4 & 5 & 6 & 7 & 8 & 9 & 10 & 11 & 12 \\
\hline 1. FR & 1.00 & & & & & & & & & & & \\
\hline 2. HR & -0.02 & 1.00 & & & & & & & & & & \\
\hline 3. CR & $-0.14^{*}$ & $-0.18 * *$ & 1.00 & & & & & & & & & \\
\hline 4. PDF & $0.18^{* *}$ & 0.03 & $-0.13^{*}$ & 1.00 & & & & & & & & \\
\hline 5. IJF & 0.08 & 0.00 & -0.06 & $0.55 * *$ & 1.00 & & & & & & & \\
\hline 6. HPF & 0.07 & 0.01 & $-0.11 *$ & $0.64 * *$ & $0.68 * *$ & 1.00 & & & & & & \\
\hline 7. $\mathrm{PDH}$ & 0.08 & $0.21 * *$ & $-0.19 * *$ & $0.63 * *$ & $0.35 * *$ & $0.43 * *$ & 1.00 & & & & & \\
\hline 8. IJH & 0.04 & 0.03 & -0.10 & $0.45 * *$ & $0.60 * *$ & $0.55^{* *}$ & $0.57 * *$ & 1.00 & & & & \\
\hline 9. HPH & 0.07 & 0.10 & $-0.15^{* *}$ & $0.47 * *$ & $0.58 * *$ & $0.70 * *$ & $0.55 * *$ & $0.82 * *$ & 1.00 & & & \\
\hline 10. PDHM & 0.05 & 0.08 & $-0.18^{* *}$ & $0.32 * *$ & $0.43 * *$ & $0.45^{* *}$ & $0.41 * *$ & $0.50 * *$ & $0.55^{* *}$ & 1.00 & & \\
\hline 11. IJHM & 0.07 & 0.10 & $-0.20 * *$ & $0.31 * *$ & $0.41 * *$ & $0.46^{* *}$ & $0.39 * *$ & $0.47 * *$ & $0.51 * *$ & $0.85 * *$ & 1.00 & \\
\hline 12. НРНМ & 0.06 & $0.12 *$ & $-0.22 * *$ & $0.28 * *$ & $0.33 * *$ & $0.48 * *$ & $0.34 * *$ & $0.40 * *$ & $0.48 * *$ & $0.75 * *$ & $0.88 * *$ & 1.00 \\
\hline
\end{tabular}

1: flood risk; 2: hurricane risk; 3: chemical risk; 4: property damage from a flood; 5: injury from a flood; 6: health problems from a flood; 7: property damage from a hurricane; 8 : injury from a hurricane; 9: health problems from a hurricane; 10: property damage from a hazardous material release; 11: injury from a hazardous material release; 12: health problems from a hazardous material release.

$*$. $\mathrm{p}<0.05 . * * . \mathrm{p}<0.01 . \mathrm{N}=313$ to 321 .

correlations indicated that the higher the level of education, the less the concern of PDF, IJH, HPH, and PDHM. SEX (male coded as "1") was correlated with all of the risk perception items (IJF: $r=-0.15$; HPF: $r=-0.13$; PDH: $r=-0.16$; IJH: $\mathrm{r}=-0.17$; HPH: $\mathrm{r}=-0.17$; PDHM: $\mathrm{r}=-0.22$ : IJHM: $\mathrm{r}=$ -0.16 ; HPHM: $r=-0.17)$, except for PDF $(r=-0.11)$. These correlations indicated that females had a higher level of perceived risk than did males. INCOME (yearly household income) was correlated with perceived risk of $\operatorname{HPF}(r=-0.17)$, PDH $(r=-0.14)$, and HPH $(r=-0.13)$. TENURE (tenure at present home) was positively correlated only with perceived risk of $\mathrm{PDH}(\mathrm{r}=0.17)$.

\subsection{Scientifically Estimated Environmental Risks and Perceived Risks}

As shown in Table 9, scientifically estimated risks of natural hazards were significantly related only to respondents' ratings of property damage from a flood $(\mathrm{r}=0.18)$ and property damage from a hurricane $(r=0.21)$. However, scientifically estimated flood and hurricane risks were not sig- 
nificantly related to perceptions of injury and health problems from these hazards. Hazardous material risk was related to all three categories of risk perception of a hazardous material release with correlation coefficients of $-0.18,-0.20$, and -0.22 (all significant $\mathrm{p}<0.01$ ). These coefficients have negative signs because chemical risk was measured by distance from the nearest TRI facility, so risk is inversely related to distance.

\section{Conclusions}

\subsection{Household Characteristics and Environmental Risk Perceptions}

Previous studies maintained that higher levels of public risk perceptions were found among females (Slovic, 1992; Savage, 1993), ethnic minorities (Adeola, 1995), less educated, and poorer people, (Pilisuk and Acredolo, 1988), younger people, and low-income groups (Savage, 1993). Thus, the second hypothesis of this research was that public risk perceptions of hurricanes, floods, and toxic chemical releases are related to household characteristics.

The results showed that there were no statistically significant relationships between some household characteristics (i.e., age, household size, marital status) and risk perception indicators addressing potential consequences of any occurrence resulting from a flood, hurricane, or hazardous material release. Thus, the results did not support Savage's findings (1993) that younger people had a higher level of risk perception. Partially consistent with the findings of Pilisuk \& Acredolo (1988), educational attainment had a statistically significant relationship with property damage from a hurricane (PDH), the injury from a hurricane (IJH), and property damage from a hazardous material release (PDHM). These results indicate that the higher the level of education, the lower the concern of PDF, IJH, and PDHM. Gender (male $=1$ ) was correlated, except for property damage from a flood, with all of the risk perception items. These correlations indicated that females had a higher level of perceived risk than did males, which support the findings of Slovic (1992) and Savage (1993). Partly consistent with the result of Savage (1993), yearly household income was also correlated with all risk perception attributes except for property damage from a flood (PDF) and injury from a flood (IJF). Blacks had a higher level of perceived risk of injury from a flood, health problems from a hurricane, property damage from a hazardous material, compared with Whites. Finally, tenure at present residence was positively related only to perceived damage from a hurricane, but not related to any risk perception indicators. It is noticeable that the persons with the longest duration of current residence had no higher threat perception of chemical hazards, even though they were most vulnerable to the level of chemical risk.
In sum, the results of this research showed little differences in risk perceptions of technological and natural hazards across groups with different household characteristics. Specifically, risk perceptions of the respondents did not differ by age, household size, and marital status. By contrast, educational level, gender, and yearly household income were related to perceived risk of the natural hazards, whereas educational attainment and gender were related to perceived risk of hazardous material releases. Persons who are White, more educated, male, and have higher income tended to have a lower concern about the consequences of the natural hazards, whereas persons who are more educated and male tended to have a lower concern about the consequences of technological hazards. Additionally, the results showed no apparent evidence that there existed a significant difference among different household characteristic groups between their levels of risk perceptions of property damage and their levels of risk perceptions of injury and health problems.

\subsection{SEERs and Risk Perceptions}

Because disasters of floods, hurricanes, and hazardous material releases can result in effects including loss of life and property, health problems, and community disruption, people at risk of environmental hazards would be expected to have greater risk perceptions than those at no risk (Bullard, 1990; Maser \& Solomon, 1990). Thus, the third hypothesis of this research is that SEERs of natural and technological hazards are related to risk perception of floods, hurricanes, and toxic chemical releases. The rationale for this hypothesis is that risk perception can be based upon scientific data released by public authorities that both are based upon environmental cues such as proximity to hazard sources - rivers, bays, and chemical plants (Drabek, 1986).

The results of this research demonstrated that SEER of floods was positively related to respondents' perception of property damage from a flood, but not related to injury or heath problems from a flood. Also, SEER of hurricanes was related only to property damage from a hurricane, but not related to injury or health problems from a hurricane. These results suggest that environmental cues such as proximity to rivers and bays do not much contribute to an increase in the respondents' perception of safety and health problems resulting from natural hazards. The fact that there was a significant correlation with property damage suggests that risk area residents believe that they can protect themselves (e.g., by evacuating), but not their property.

Consistent with Hypothesis 3, SEER of hazardous materials was related to all three categories of risk perception of a hazardous material release; property damage, injury, and health problems from a hazardous material release. This result indicates that the higher the SEER of chemical haz- 
ard, the higher the risk perception associated with that hazard, suspecting that proximity to hazardous material facilities is an environmental cue that increases the level of respondents' perception of technological hazards.

\subsection{Contributions and Future Research}

This research contributes to the literature in many ways. First, this research tests, for the first time, whether household characteristics are related to multiple environmental risks of floods, hurricanes and hazardous materials, as well as related to perceived risk of potential consequences from these hazards. The results show that household characteristics have low correlations with SEER and perceived risk of natural hazards, but are significantly correlated with SEER of hazardous materials. It is notable that there is no signification correlation between household characteristics and perceived risk of hazardous materials except for educational attainment and gender.

Second, this research contributes to the literature on environmental hazards by examining the relationship between SEERs and public risk perceptions. This overcomes a major limitation of existing research, which has failed to examine the potential difference between scientifically estimated risk and perceived risk - in some case even using the scientifically estimated risk (i.e., distance from a hazardous facility to sampled houses) as a proxy for public risk perceptions in testing a relationship between environmental risk and housing prices (Clark et al., 1997). The finding that SEERs and perceived risks are consistently related for chemical hazard but not for flood or hurricane hazard shows that SEERs and risk perceptions are not equivalent.

Finally, several areas of future research are suggested. Above all, this study indicated that minority groups, especially Blacks, had a disproportionate exposure to chemical risk. An old black woman wrote on her questionnaire that since she moved to her present residence, the number of chemical facilities increased in her surrounding area, the prices of nearby houses decreased, and some neighbors have had symptoms of health problems. The inequitable distribution of hazardous material faculties is an issue of the environmental justice (Liu, 1996; Yoon, 1996), which needs additional research to examine the process of hazardous material facilities' site selection. Such research can test whether facility owners target ethnic minorities, or whether they simply select sites adjacent to existing facilities where the land is cheap, or where the tax rate is low.

\section{References}

Adeola, F.O. (1995) Demographic and socioeconomic differentials in residential propinquity to hazardous waste sites and environ- mental illness. Journal of the Community Development Society, $26,15-40$.

Bullard, R.D. (1990) Dumping in Dixie: Race, class, and environmental quality. Boulder, CO: Westview Press.

Burn, D.H. (1999) Perceptions of flood risk: A case study of the Red River flood of 1997. Water Resources Research, 35, 3451-3458.

Clark, D.E., Michelbrink, L., Allison, T. and Metz, W. C. (1997) Nuclear power plants and residential housing prices. Growth and Change, 28, 496-519.

Cutter, S.C. (1981) Community concern for pollution: Social and environmental influences. Environment and Behavior, 13, 105124.

Drabek, T. (1986) Human system responses to disaster: An inventory of sociological findings. New York: Springer Verlag.

Kates, R.W. and Kasperson, J.X. (1983) Comparative risk analysis of technological hazards (A review). Proceedings of the National Academy of Sciences of the United States of America, 80, 7027-7038.

Lindell, M.K. and Perry, R.W. (1992) Behavioral foundations of community emergency planning. Washington DC: Hemisphere.

Liu, F. (1996). Environmental equity: Linking population distribution with environmental risk distribution. Ph.D. Dissertation, the University of Pennsylvania.

Maser, J. D. and Solomon, S.D. (1990) Psychosocial and psychological consequences of exposure to extreme stressors. Journal of Applied Social Psychology, 20, 1725-1732.

Mileti, D.S., Drabek, T.E. and Haas, J.E. (1975) Human systems in extreme environments. Boulder: University of Colorado, Institute of Behavioral Science.

Pilisuk, M. and Acredolo, C. (1988) Fear of technological hazards: one concern or many? Social Behavior, 3, 17-24.

Savage, I. (1993) Demographic influences on risk perceptions. Risk Analysis, 13, 413-420.

Sjoberg, L. (2002) Are received risk perception models alive and well? Risk Analysis, 22, 665-669.

Slovic, P. (1987) Perception of risk. Science, 236, 280-285.

Slovic, P. (1992) Perception of risk: reflections on the psychometric paradigm. In S. Krimsky \& D. Golding (Ed.), Social theories of risk (pp. 117-152). Westport, CT: Praeger.

Sorensen, J. and White, G. (1980) Natural hazards: A cross-cultural perspective. In I. Altman et al. (Ed), Human Behavior and the Environment: Environment and Culture (pp. 279-318). New York: Plenum Press.

Starr, C. (1969) Social benefits vs. technological risk. Science, 165, 1232-1238.

Taylor, S.E. (1989) Positive illusions. New York: Basic Books.

Yoon, E. (1996) The impact of waste facilities on property values: An interrupted time series analysis of waste incinerator plant siting in Seoul, Korea. Ph.D. Dissertation, Cleveland State University.

Van Liere, K.D. and Dunlap, R.E. (1980) The social bases of environmental concern: A review of hypotheses, explanations, and empirical evidence. Public Opinion Quarterly 44, 181-197.

논문접수일 : 11년 02월 22일

(심사의뢰일 : 11 년 03 월 18 일

() 심사완료일 : 11년 08월 01일 